\title{
THE APPLICATION OF PROFIT SHARING \\ OF SHIRKAH CONTRACT DURING NEW NORMAL ERA \\ AT MICRO, SMALL, AND MEDIUM ENTERPRISE (MSME), WARUNG SATE JOENEDIN SAMARINDA
}

\author{
Nurul Fadhilah \\ Universitas Islam Negeri Sultan Aji Muhammad Idris Samarinda \\ e-mail: nurul.fadhilah@uinsi.ac.id
}

\begin{abstract}
This research aims at answering some research questions: How was the shirkah system and the implementation of profit sharing in the new normal era, as well as the benefits and obstacles of implementing the shirkah contract at Warung Sate Joenedin. The research method used is qualitative descriptive analysis approach. Data collection is conducted through observation, documentation, and a direct interview with informants, namely Warung Sate Joenedin partners. The results reveal that the collaboration between the partners of Warung Sate Joenedin is in the form of shirkah inan. Based on the research results, it can be concluded that the cooperation carried out by Warung Sate Joenedin follows the term cooperation from sharia economics perspective. The implementation of profit sharing is based on an agreement, while losses are borned by each partner based on the capital stock. This shirkah cooperation is beneficial for partners, while Warung Sate Joenedin has not experienced losses. In line with the conclusion based on the Islamic economics perspective, the researchers suggested that the cooperation between Warung Sate Joenedin companies should be sustainable.
\end{abstract}

Keywords: cooperation; shirkah inān; new normal era; Warung Sate Joenedin

\section{Introduction}

Micro, Small, and Medium Enterprises (MSMEs) are an essential part of economic growth and development globally. MSMEs are considered the basis of economic growth not only in developing countries but also in developed countries. MSMEs are considered necessary in developed countries because this business group can accommodate the most workers compared to large businesses. On the other hand, MSMEs have the most considerable contribution to gross domestic product (GDP) formation and growth compared to the contribution of large businesses. ${ }^{1}$

In addition, MSMEs also play an essential role in supporting the improvement of the community's economy at the city and district levels. MSMEs are producer entities and large enough consumers so that the money in the community eventually revolves from and by MSMEs themselves. ${ }^{2}$ MSMEs have a proportion of 99.99 percent of the number of business

\footnotetext{
${ }^{1}$ Dani Sugiri, "Menyelamatkan Usaha Mikro, Kecil dan Menengah dari Dampak Pandemi Covid-19," Fokus Bisnis: Media Pengkajian Manajemen dan Akuntansi, Volume 19, Number 1 (2020), 76-86.

${ }^{2}$ Lies Maria Hamza and Devi Agustien, "Pengaruh Perkembangan Usaha Mikro, Kecil, dan Menengah Terhadap Pendapatan Nasional Pada Sektor UMKM Di Indonesia," Jurnal Ekonomi Pembangunan, Volume 8, Number 2 (2019), 127-35.
} 
actors in Indonesia or as many as 56,534,592 units. Therefore, synergy is needed to improve and maintain MSMEs. ${ }^{3}$

However, due to the covid-19 pandemic, many businesses, including MSMEs, experienced a decline in turnover. Covid-19 is an infectious disease caused by the chronic respiratory syndrome coronavirus. This virus is a large family of coronaviruses that cause respiratory tract infections, such as flu, MERS (Middle East Respiratory Syndrome), and SARS (Severe Acute Respiratory Syndrome). Covid-19 is a new type of coronavirus discovered in Wuhan, Hubei, China, in 2019.

Due to covid-19, the unemployment rate has increased. Public attitudes regarding the covid-19 pandemic and social restrictions policies have changed on a small and large scale. Concerns about being exposed and implementing large-scale social restrictions (PSBB) are challenges for the community to adapt to the existing conditions. ${ }^{4}$ These differences in people's attitudes affect the acceleration of economic development. This global pandemic has caused economic instability, especially for MSME actors who have experienced a direct result in the form of a decrease in sales turnover. The decrease is due to the Government's appeal to follow the Large-Scale Social Restrictions (LSSR), which urges people to stay at home so that many MSMEs have to close temporarily. ${ }^{5}$

It was stated in a field study according to Bank Indonesia that 72.6 percent of Micro, Small and Medium Enterprises (MSMEs) experienced the impact of the covid-19 pandemic. ${ }^{6}$ Then, according to data processed by the Economic Research Center of the Indonesian Institute of Sciences (P2E-LIPI), the effect of the decline in tourism on MSMEs in the micro culinary and beverage business reached 27 percent. At the same time, the impact on small culinary and beverage businesses was 1.77 percent, and medium-sized businesses were 0.07 percent. It was a sign that the covid-19 pandemic was very influential in reducing the development of MSMEs.

As a result of this economic downturn, some countries are slowly implementing the New Normal to push back the wheels of the economy. They are slowly starting to lift social restrictions to save people's jobs and restart economic activity. Indonesia is no exception. The Government has started a new normal campaign by allowing employees under 45 years old to return to work. The new normal is characterized by new production and consumption patterns through increasingly accelerated digitization and automation. ${ }^{7}$

MSME actors must have a strategy to survive during this pandemic and adapt to the conditions that occur. Some strategies to maintain business include selling through e-

\footnotetext{
${ }^{3}$ Sudati Nur Sarfiah, et al, "UMKM Sebagai Pilar Membangun Ekonomi Bangsa," Jurnal REP (Riset Ekonomi Pembangunan, Volume 4, Number 2 (2019), 137-46.

${ }^{4}$ Wiwik Suprihatin, "Analisis Perilaku Konsumen Wisatawan Era Pandemi Covid-19 (Studi Kasus Pariwisata di Nusa Tenggara Barat),” BESTARI Volume 1, Number 1 (2020), 56-66.

5 Januar Eko Aryansah and Dwi Mirani, "Strategi Bertahan Usaha Mikro Kecil dan Menengah Sektor Kuliner di Masa Pandemi Covid-19," Prosiding Applicable Innovation of Engineering and Science Research, Number 1 (2020), 323-29.

${ }^{6}$ Kunthi Fahmar Sandy, "Survei BI: 72,6 Persen UMKM Turun Omzet Akibat Pandemi Covid-19," dalam https://www.inews.id/finance/makro/survei-bi-726-persen-umkm-turun-omzet-akibat-pandemi-covid-19.

Diakses pada 11 Desember 2020.

7 Endah Marendah Ratnaningtyas, "Dampak dan Strategi UMKM (Usaha Mikro Kecil dan Menengah) Menghadapi The New Normal," EBBANK, Volume 11, Number 1 (2020), 63-70.
} 
commerce, marketing products using digital technology, and improving the quality of products and services. ${ }^{8}$

In addition to those strategies, the Islamic distribution management strategy can be a solution to overcome the decline in the development of MSMEs. ${ }^{9}$ This distribution strategy is commercial distribution in cooperation with non-usury contracts or what is called shirkah. The practice of shirkah has a good impact on the MSMEs and people around them. In addition, shirkah can increasing their incomes or reducing unemployment. ${ }^{10}$

The shirkah model is a concept that can precisely solve capital problems. On the one hand, Islamic principles state that everything used by others is entitled to mutually beneficial compensation, whether for capital goods, labor, or rental items. On the other hand, Islam firmly rejects compensation for capital goods in the form of interest. ${ }^{11}$ Hopefully, the impact of the crisis can be reduced by using venture capital assistance. ${ }^{12}$

Islamic economists support the vital role of shirkah in community economic growth (CEG). Economic paralysis often occurs because the capital owners cannot manage their capital or, on the contrary, can manage capital but do not have the capital. Shirkah can be a justified solution in Islamic sharia. ${ }^{13}$ Warung Sate Joenedin is one of the MSMEs that have successfully started a business amid a pandemic with the profit-sharing concept. This study aimed to determine how the shirkah system and the implementation of the shirkah profit sharing contract at Warung Sate Joenedin Samarinda and the benefits and obstacles found in running the business.

\section{Research Methods}

This research was qualitative research with a case study approach. The research method was also known as a naturalistic research method because the research process was carried out naturally. ${ }^{14}$ At the same time, the case study approach served to collect data and gain meaning and understanding from existing cases. ${ }^{15}$ The data collection technique used observation, interview, and documentation techniques regarding the collaboration implementation. Furthermore, the data processing was carried out in the form of editing and organizing. The data analysis technique used was descriptive qualitative, which meant using analysis that described a meaning accepted by the researcher accompanied by showing the evidence. Furthermore, it was abstracted into research results and suggestions that MSMEs can adopt. ${ }^{16}$

\footnotetext{
${ }^{8}$ Wan Laura Hardilawati, "Strategi Bertahan UMKM di Tengah Pandemi Covid-19," Jurnal Akuntansi dan Ekonomika, Volume 10, Number 1 (2020), 89-98.

9 Nurul Fadhilah, "Strategi Manajemen Distribusi Islam dalam Mengatasi Krisis Ekonomi Akibat Pandemi Covid-19," Business Innovation and Entrepreneurship Journal, Volume 2, Number 4 (2020), 242-51.

${ }^{10}$ Nur Syamsiyah, “Analisis Praktik Akad Syirkah Pada Usaha Mikro, Kecil, dan Menengah (UMKM) Batik Berdasarkan Perspektif Taqiyuddin al-Nabhani: Studi Kasus di UD. Rengganis Collection, Desa Selowogo, Kecamatan Bungatan, Kabupaten Situbondo, Jawa Timur” (Thesis--UIN Maulana Malik Ibrahim, 2019).

${ }^{11}$ M. Umar Chapra, Islam dan Tantangan Ekonomi: Islamisasi Ekonomi Kontemporer (Surabaya: Risalah Gusti, 1999), 75.

12 Nurul Fadhilah, "Sumbangan Pemikiran dan Perspektif Akademisi," Politala Press (2020), 94.

${ }^{13}$ Yusuf al-Qardhawi, Norma dan Etika: Ekonomi Islam, Cet. 2 (Jakarta: Gema Insani Press, 1997), 53.

${ }^{14}$ Sugiyono, Metode Penelitian Bisnis Pendekatan Kuantitatif, Kualitatif, dan R\&D (Bandung: Alfabeta, 2017), 42.

${ }^{15}$ M. Junaidi Ghoni, Metodologi Penelitian Kualitatif(Jogjakarta: Ar-Ruzz Media, 2012), 36.

${ }^{16}$ Sugiyono, Metode Penelitian Bisnis, 58.
} 


\section{Definition of Shirkah Contract}

According to the word's origin, 'aqd (contract) means an agreement between two people, either in writing or verbally. In particular, fiqh scholars interpret 'aqd as an agreement made with ijab-qabul according to Shariah provision, which will impact the object being contracted. ${ }^{17}$ Shirkah is a collaboration between two or more people in a business. The profits and losses are shared. ${ }^{18}$ In principle, shirkah is different from the corporate model in the capitalist economic system. The differences were not only in the absence of interest practices in this model but also and in the transaction formation, operations, and profits and losses formation.

Some of the terminological definitions of shirkah conveyed by the four of fiqh scholars are as follows. According to the Hanafiyah scholars, shirkah is a contract between parties who agree on capital and profits. According to Malikiyah scholars, shirkah is the permissibility for each party to join the association. It means that each party permits the other party to use shirkah assets (objects). According to Shafi'iyah and Hanabilah scholars, shirkah applies rights to something for two or more parties with the alliance's aim. ${ }^{19}$

Islam has justified a muslim to use his property, whether it is done individually or in cooperation. Therefore, Islam justifies those who have the capital to run a business in the form of shirkah. Shirkah transactions require ijab-qabul at the same time, just like any other transaction. The form of the $\overline{i j} a b$ is "I entered into a company with you in this matter", then the other replied "I accept". However, it is not necessary to always use the expressions above. The important thing is that it has the same meaning. That is, in stating the ijab-qabul, there must be a meaning that shows that one of them invites the other --either orally or in writing -to cooperate (shirkah) in an affair. Then, the others accept the shirkah. Therefore, the agreement to only perform shirkah is still considered insufficient, including an agreement to provide capital for shirkah only is also still considered not enough, but must contain the meaning of cooperation (doing shirkah) in a business affair. ${ }^{20}$

\section{The Legal Basis of Shirkah}

The law of shirkah is permissible or mubah. ${ }^{21}$ It is shown by the abandonment of shirkah practice by the Prophet Muhammad carried out by the Islamic community at that time. ${ }^{22}$ Some of the arguments of the al-Quran and Hadith that explain shirkah include:

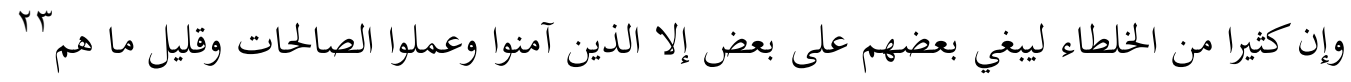

"Indeed, most of those who practice syirkah, some of them do wrong to others, except those who believe and do righteous deeds.

\footnotetext{
${ }^{17}$ Rahmat Syafe'i, Fiqih Muamalah (Bandung: Pustaka Setia, 2000), 132.

18 Deny Setiawan, "Kerja Sama (Syirkah) dalam Ekonomi Islam," Jurnal Ekonomi, Volume 21, Number 3 (2013), 73-84.

${ }^{19}$ Ghufron Masadi, Fiqh Muamalah Kontekstual (Jakarta: PT. Raja Grafindo Persada, 2002), 81.

20 Taqiyuddin al-Nabhani, Membangun Sistem Ekonomi Alternatif: Perspektif Islam, Trans. Moh. Maghfur Wachid (Surabaya: Risalah Gusti, 1996), 95.

21 J. Juliana et al., "Shirkah: Implementation of Fresh Water Fishing Fishery (KJA)," Tsarwatica (Islamic Economic, Accounting, and Management Journal, Volume 1, Number 2 (2020), 65-73.

22 Deny Setiawan, "Kerja Sama (Syirkah)", 73-84.

${ }^{23}$ al-Quran, 38:24.
} 
Based on the evidence of Prophet Muhammad's hadith, in his taqriri (recognition) of shirkah, it can be concluded that when he was sent as a messenger of Allah, people had muamalah through shirkah, and he confirmed it. Thus, the Prophet's acknowledgment of shirkah practice by many people was a sharia argument for its permissibility.

Shirkah may be done between muslims, kafir dhimmis, or between a muslim and a kafir dhimmi. Therefore, a muslim can also do shirkah with people of different religions as long as shirkah is an effort that is not forbidden for muslims. As stated by a hadith by Muslim by Abdullah bin Umar "The Messenger of Allah once employed the people of Khaibar who were Jews to get a share of the harvest of fruit and plants" (HR Muslim).

\section{Terms and Pillars of Shirkah}

According to the Maliki scholars, the conditions relating to the person performing the contract are independence, puberty (baligh), and intelligence. Shafi'iyah believes that the only valid shirkah is shirkah inän while the other shirkah are invalid. Abd al-Rahman al-Jaziri also explains that shirkah pillars are two people in union, the subject and object of the shirkah contract, property, and work. Idris Achmad explains some conditions for shirkah as follows. First, issuing words that indicate each union member's permission to the party who will be the property controller. Second, the union members trust each other because each of them is the representative of the others. Third, mixing assets so that the rights of each cannot be distinguished, either in the form of currency or in other forms.

The shirkah pillars are disputed by scholars. According to Hanafiyah scholars, there are two shirkah pillars, namely $\overline{i j} a b$ and qabul, or in other words is 'aqd/contract. The contract determines the existence of shirkah. According to Hanafiyah, the conditions related to shirkah are divided into the following four parts. First, something related to all forms of shirkah, both with property and others. In this case, there are two conditions, namely concerning the contracted object, it must be accepted as a representative; and concerning profits, the distribution of profits must be precise and can be known by two parties, for example, half, one third and others. Second, something related to shirkah al-mal (wealth). In this case, two things must be met: the capital used as the shirkah contract object comes from payment instruments (nuqüd) such as riyal and rupiah; and something which is used as capital (principal assets) is come when shirkah contract is carried out, both in the same or different amounts. Third, something related to shirkah mufawadah. It is required that capital (principal property) in shirkah mufawadah must be the same, for expert shirkah for kafalah, for those who are used as contract objects, general shirkah is required, namely on all commerce types on trade. Fourth, the conditions relating to shirkah inän are the same as those of shirkah mufawadah.

According to the Maliki scholars, the conditions related to the person performing the contract are independence, puberty, and intelligence. Shafi'iyah believes that the only valid shirkah is shirkah inān while the other shirkah are invalid. The conditions for shirkah are explained by Idris Achmad as follows. First, issuing words indicating the permission of each union member to the party who will control the property. Second, the union members trust each other because each of them is the representative of the other. Third, mix assets so that the rights of each cannot be distinguished, either in the form of currency or in other forms. 
Most scholars agree that the 'aqd/contract is one of the things that must be done in shirkah. According to the scholars, the shirkah pillars include sighah (ijab and qabul), al'aqidain (subject of the union), Mahal al- 'aqd (object of association). ${ }^{24}$

\section{The Fatwa (Islamic instructions of rules) of The National Sharia Council (DSN) Regarding Shirkah}

The DSN Fatwa Number 08/DSN-MUI/IV/2000 concerning Mushärakah dated April 13, 2000 states some mushärakah provisions as follows. Ijab and qabul must be stated in the contract by taking into account the following matters. First, supply and demand must explicitly indicate the purpose of the contract. Second, acceptance and supply are made at the time of contract. Third, the contract is made in writing through correspondence or by using modern ways of communication. And the parties to the contract must be legally competent and pay attention to the following. First, competent in granting or being given representative powers. Second, each partner provides funds and work, and each partner carries out the representative's job. Third, each partner has the right to manage musharakah assets in the business process.

The object of the contract such capital can be cash or business assets; may not be loaned or given to other parties except based on an agreement; and in principle, there is no guarantee, but to avoid deviations, Islamic Financial Institution (LKS) can ask for guarantees. The object of the contract such work stated that a partner may do more work than another partner, claiming an additional share of the profits for himself; and each partner carries out work on behalf of himself and behalf of his partner. The position of each in the organization must be described in the contract. ${ }^{25}$

The object of the contract such profit mentioned that first, advantages must be quantified to avoid differences and disputes. Second, each partner's profits must be shared proportionately based on profits, and no pre-set amount is assigned to a partner. Third, a partner may propose that if the profit exceeds a certain amount, the excess over that percentage is given to him. Fourth, the profit-sharing system must be clearly stated in the contract. The object of the contract such loss should be divided among the partners in proportion according to their respective capitals. For operational costs must be charged to joint capital. If one of the parties does not fulfill its obligations or if there is a dispute between the parties, then the settlement is carried out through the National Sharia Arbitration Board after no agreement is reached through deliberation.

\section{Kinds and Types of Shirkah}

Shirkah is broadly divided into two types, namely shirkah of property rights (shirkah alamlak) and shirkah of transactions (shirkah al-'uquid). Shirkah al-amlak is an alliance between two or more people to have a joint property without having a shirkah contract. Shirkah in this category is divided into two forms. First, shirkah ikhtiyäriyah, is shirkah that occurs due to the actions and wishes of the parties involved in the association. Second,

\footnotetext{
${ }^{24}$ J. Juliana et al., "Shirkah: Implementation", 65-73.

${ }^{25}$ Mardani, Fiqh Ekonomi Syari'ah: Fiqh Muamalah (Jakarta: Persada Media Group, 2013), 26.
} 
shirkah ijbäriyah, is shirkah that occurs without the wishes of the parties concerned, such as an association of heirs.

Shirkah al- 'uquid is an alliance between two or more people to bind themselves in a capital and profit association. Regarding the division of shirkah al- 'uquid, the scholars of fiqh have different opinions. Hambali scholars divides it into five forms, namely shirkah inān, mufawadah, abdan, wujuh, and mudarabah. The scholars of Maliki divide it into four, namely shirkah inān, mufawadah, abdān, and mudärabah. The scholars of Shafi'i only justify shirkah inān and mudärabah. Furthermore, Hanafi scholars divide it into three, namely shirkah alamwal (union in capital or property), shirkah al-a'mal (union in work), and shirkah al-wujuh (union without capital). ${ }^{26}$

Some understanding of the various types of shirkah uqud are as follows:

1. Shirkah al-amwal, an alliance between two or more investors in a particular business by collecting joint capital and sharing the profits and risks of loss based on an agreement.

2. Shirkah al-a'mal or shirkah al-abdān, an alliance of two or more workers to do a job. The work's results and wages are divided according to their agreement.

3. Shirkah al-wujuh, an alliance between two business parties to collaborate where each party does not include capital. They run their business based on the trust of third parties.

4. Shirkah al-inan, an alliance where the position and composition of the parties involved are not the same both in terms of capital, work, and profits, and risks of loss.

5. Shirkah al-mufawadah, which is an alliance where the position and composition of the parties involved are the same, both in terms of capital, work, as well as in terms of profits and risks of loss.

6. Shirkah al-mudärabah, an alliance between capital owners and experts in trading or entrepreneurs, where the investors provide all of the working capital. In other words, an association between capital on the one hand and work on the other. Profits are shared based on an agreement, while the investors bear losses. ${ }^{27}$

\section{The Cancellation of The Shirkah Contract}

According to the scholars, the cancellation of the shirkah contract occurs when things happen, such as reaching the specified period. The period for the shirkah contract is determined by both parties or when one of the parties dies. It can also include the fleeing party. However, if there are more than two shirkah members, only those who pass away are canceled. Shirkah continues on members who are still alive. If the deceased members' heirs wish to participate in shirkah, a new agreement is made for the heirs concerned, after which one of the parties wishes to discontinue the shirkah. Fiqh experts state that if a union is not binding, so a violation that causes the shirkah to be invalid can happen, such as a party betrays or violates an agreement made together. One of the parties loses his ability to act legally, like continuously going crazy. ${ }^{28}$

According to Ahmad Azhar Basyir, there are six leading causes for the end of shirkah that has been contracted by the parties who perform shirkah. First, shirkah will end if one of

\footnotetext{
${ }^{26}$ Nasrun Haroen, Fiqh Muamalah (Jakarta: Gaya Media Pratama, 2000), 162.

${ }^{27}$ Ghufron Masadi, Fiqh Muamalah Kontekstual, 81.

${ }^{28}$ J. Juliana et al., "Shirkah: Implementation", 65-73.
} 
the parties cancels it, even though without the other party's consent. It is because shirkah is a contract that occurs based on both parties' voluntarily that there is no necessity to implement it if one of the parties does not want it anymore. Second, one of the parties loses the ability to tasarruf (the skill of managing assets) either because of madness or for other reasons. Third, one of the parties dies. Nevertheless, if there are more than two shirkah members, only the one who passes away is canceled. Shirkah continues on members who are still alive. If the heirs of the deceased member wish to participate in the shirkah, a new agreement is made for the heirs concerned. Fourth, one of the parties is placed under pardon. The forgiveness referred to here is either due to the extravagance that occurred when the shirkah agreement was in progress or for other reasons. Fifth, one of the parties goes bankrupt, resulting in no longer having control over the assets that become shirkah shares. This opinion was expressed by the Maliki, Shafi'i, and Hambali scholars. Hanafi thinks that the bankruptcy situation does not invalidate the agreement made by the person concerned. Sixth, the capital of the shirkah members disappears before being spent in the name of the shirkah. If the capital disappears before mixing assets are not separated, those who bear the risk are the owners themselves. If the property disappears after a mixture is inseparable, it becomes a mutual risk. Damage that occurs after spending is a shared risk. If there are remaining assets, the shirkah can still take place with the remaining assets. ${ }^{29}$

\section{The Overview of Warung Sate (Satay Stall) Joenedin in Samarinda}

Starting from the desire to have their food stalls, three young men named Jojoe, Nedi, and Idin opened a satay stall with a cooperation agreement, which was later named Warung Sate Joenedin. Jojo is an employee of a company affected by covid-19, while Nedi and Idin have been workers at other people's satay stalls for about eight years. Warung Sate Joenedin is a food stall located on J1. Juanda in front of August 17, 1945, University of Samarinda. Samarinda is a strategic city because it connects surrounding cities/regencies to Sepinggan Balikpapan Airport, such as Tenggarong, Bontang, Sangkulirang. The location is easy to find because it is near some offices and August 17, 1945, University of Samarinda.

Warung Sate Joenedin's business was opened starting on December 01, 2020. Warung Sate Joenedin is located at Jl. Juanda No. 55, opposite August 17, 1945, University of Samarinda, East Kalimantan. The food stall has some main menus from goat, such as sate kambing (goat satay), tengkleng, gulai, and tongseng kambing. In addition, it also provides chicken menus, such as sate ayam (chicken satay) and tongseng ayam. Opening a goat satay stall is considered very appropriate, considering the lack of goat-based food stalls. In addition, the dishes in this food stall has the uniqueness of Solo, so it will be easier to recognize.

\section{Profit Sharing in Mushärakah}

The musharakah profits will be shared among the co-workers in the business based on the respective shares they have determined beforehand. The profit share of each party must be determined according to a share or percentage. In shirkah, it is also agreed that there is no definite amount for determining profits for any party. It shows that in profit sharing, the

\footnotetext{
${ }^{29}$ Deny Setiawan, "Kerja Sama (Syirkah)”, 73-84.
} 
parties in the business must be determined according to that part through a collective agreement. However, the Hambali and Hanafi jurists only support this opinion.

According to the jurists of the Maliki and Shafi'i scholars, the distribution of profits in shirkah must reflect the amount of capital invested. According to Hanafi fiqh experts, in shirkah, the profits distributed to each partner must be determined according to the total profit, not based on a certain amount of money. In the shirkah agreement, the Shafi'i and Maliki jurists argue that profits will be distributed according to the share of capital invested, which implies that a certain amount of money as profit cannot be shared with any party.

The opinion of the Hambali followers is the same as that of the Hanafi followers, namely that profits must be shared among partners according to predetermined provisions, as long as the form of musharakah is considered simple is no difference of opinion on the matter. An increase in dirhams more than the capital invested in one particular party may not be determined. If one of the two parties stipulates a certain amount of dirham in shirkah or mudarabah, it cannot be validated. ${ }^{30}$

\section{The Venture Capital of Warung Joenedin}

When starting a business, people will always need venture capital. If people do not have enough savings to start a business, most usually borrow funds from a bank, or it can be called bank credit. However, in Islamic law, bank loans/credits are closely related to the interest ( riba) system, so bank credit is included in the usury category. To avoid usury, Islam provides a solution, namely a cooperative system called shirkah. The work system is a series of work procedures that form a particular roundness pattern to carry out a work field.

A shirkah system is a cooperation contract between two or more people who agree to do work of a financial nature to make a profit. ${ }^{31}$ In a sense, the parties who are members of this company have each other's role in utilizing assets/managing wealth to profit. The joining parties must contribute in the form of funds that serve as initial capital. At the same time, they agreed that the future profits and losses of the business would be shared. In this system, investors and entrepreneurs share the same vision and mission, although their duties and functions are different. The shirkah contract is also not based on a debt contract so that the capital owner is not allowed to ask for guarantees from the business manager. According to the agreement, the capital owner has entrusted their capital to business managers. In addition, a business manager can manage a business to generate profits to be shared.

Warung Sate Joenedin was founded by three partners, namely Jojo, Nedi, and Idin. Each party has their respective responsibilities in running the business they are engaged. Sharia orders a contract ('aqd) included in the shirkah contract at Warung Sate Joenedin every transaction time. All agreement forms were discussed at the beginning before Warung Sate Joenedin was formed. Some of the things discussed, among others, were about the task divisions, the goals, and objectives of establishing a joint business, sharing profits/losses, and resolving problems. ${ }^{32}$

\footnotetext{
${ }^{30}$ Udin Saripudin, "Aplikasi Akad Syirkah dalam Lembaga Keuangan Syariah,” Al Amwal (Hukum Ekonomi Syariah), Volume 1, Number 1 (2018), 26-40.

${ }^{31}$ Taqyuddin al-Nabhani, Sistem Ekonomi Islam (Bogor: Al Azhar Press, 2010), 93.

32 Jojo, Wawancara, Samarinda, 6 June 2021.
} 
The initial agreement built-in Warung Sate Joenedin agreed that this business was established to create employment. The partners have their responsibilities. The division of tasks is carried out at the beginning of the agreement. The partners are directly involved in running Warung Sate Joenedin.

Jojo's main task is as a coordinator who is coordinating all activities related to the Warung sate Joenedin. He is also in charge of recording, reporting finances, and sharing profits with other partners. Meanwhile, Nedi is in charge of the technical field, thinking technically about the desired consumer demand. On the other hand, he also finishes the marketing. Idin is in charge of preparing ingredients, such as preparing skewers of goat satay and seasonings. Apart from the three initiators, three other people help in managing the stall.

The task division above was made based on their positions at Warung Sate Joenedin. On the other hand, some tasks are carried out together regardless of their positions at Warung sate Joenedin, such as assisting in customer service. From the food stall that was formed together, each party agreed to open job vacancies for the surrounding community to work at Warung Sate Joenedin. Therefore, Warung Sate Joenedin also provided training to produce delicious dishes and have selling points to compete with other MSMEs. At first, the employees were limited to three people, until now they have employed three employees, bringing the total to six people.

Of the six employees, two are women with an average age of 20-30 years. Various kinds of obstacles faced by Warung Sate Joenedian were faced together. Setting up a business certainly requires initial capital/investment. Warung Sate Joenedin, with three parties involved in it, includes capital/investment in the form of money of 40 million rupiah. The initial capital is allocated to rent a building, buy kitchen equipment and food ingredients needed.

Initial capital is the capital needed for the establishment of the Warung Sate Joenedin. The partners who join the company carry out wealth management by involving their agency (power). One of the other mutually agreed upon contracts is related to the companies' distribution of profit/loss. The initial capital distribution is not set evenly but is considered fair, considering that managing a goat's cooking skills is considered as necessary as initial capital.

Jojo reveals that the Warung Sate Joenedin business does not use capital from the bank but only uses initial capital jointly owned and managed. It does not depend on bank loans that entrepreneurs generally use to set up their businesses or manage them. Jojo explains that Warung Sate Joenedin not only wants to make a profit but also seeks blessings. Thus, Jojo, Nedi, and Idin will try their best to manage existing capital and stay away from credit activities closely related to usury or interest issues.

Jojo chooses to reject several loan offers from the bank. He prefers to utilize and maximize existing capital. Jojo also says that Warung Sate Joenedin has collaborated with the caterer and opened orders, especially for 'aqiqah (Islamic tradition of sacrificing an animal on the occasion of a child's birth). Giving capital/wealth to Warung Sate Joenedin means that they trust each party and manage the wealth together. Thus, each party has its responsibility to run a joint business and help each other manage the company's assets so that this work runs effectively and efficiently. 


\section{Implications of The Practice of Shirkah at The Warung Sate Joenedin}

Shirkah or cooperation is one form of muamalah activity that is needed in human life. Because basically, humans cannot live alone without the help of others. For this reason, it is common if there are various forms of cooperation carried out by the community nowadays. One of them is shirkah.

With this effort, it is hoped that it can help the community's economy, increase income, and reduce unemployment in Samarinda. It will indirectly reduce the unemployment rate. It requires solid teamwork in Warung Sate Joenedin development to achieve maximum results. Jojo and his team are always active in promoting social media to know about the Warung Sate Solo. Even, Warung Sate Joenedin has regular customers from Tenggarong.

Information by word of mouth, from one community to another, Warung Sate Joenedin began to be the subject of discussion. Several agencies also make this place for visits to entertain guests outside the area. Through this, Warung Sate Joenedin is increasingly known to the people of Samarinda city or outside Samarinda. It is hoped that Warung Sate Joenedin can create employment opportunities to reduce the unemployment rate and increase the surrounding community's income and welfare. It is hoped that the community will well receive this effort.

Warung Sate Joenedin's sales were around 46 million rupiahs in the first month, and continued to rise to the next month. Jojo and his team are optimistic that if Warung Sate Joenedin is known to the public, its income will continue to increase. On the other hand, the Warung Sate Joenedin is consistent in maintaining food quality, such as goat selection techniques and goat slaughtering are special skills so that goat food does not tend to smell and is soft. Another quality is goat skewers specially ordered from Java, and the charcoal used is coconut shell charcoal. Dine-in customers usually come back again at another time. It indicates that the Warung Sate Joenedin is immensely satisfying to customers.

In connection with the food price in the Warung Sate Joenedin, it may be considered relatively expensive. However, it is only natural because it is directly proportional to the quality of the food served. It is the advantage of Warung Sate Joenedin to maintain the food quality. Meanwhile, with the calculation of wages, Jojo and his partners enforce the division of wages per day. Wages are paid at the end of the week. Employees are valued at 70.000 rupiah per day and are given a bonus if their daily income reaches a certain amount. If daily sales reach 2 million rupiah and above, then the bonus is 10.000 rupiah/day. If 3 million rupiah and above, the bonus is 20.000 rupiah/day, and so on. It is done so that employees work harder and pray.

On the other hand, opening a goat satay stall is a business that requires tenacity. In addition, trust in one another must be strong. It is crucial and must be instilled to create an environment of mutual trust, no prejudice, and honesty. At Warung Sate Joenedin, the trust between the initiators and the workforce is firm.

\section{Shirkah System in Warung Sate Joenedin}

Looking at the shirkah practical that is applied in Warung Sate Joenedin and analyzing the type of cooperation that is used, the researcher states that the type of cooperation (shirkah) applied is shirkah al-inān, where, it is a company of two or more people by including their 
respective assets. In other words, there are two or more people in shirkah al-inān who work together to manage assets by involving their bodies (strengths), and the profit is divided between them. Shirkah transactions require ijab-qabul at the same time, just like any other transaction. The form of the $\overline{i j} a b$ is "I entered into a company with you in this matter," then, the other replied "I accept." However, it is not necessary to always use the expressions above. The important thing is that it has the same meaning. That is, in stating the ijab-qabul, there must be a meaning that shows that one of them invites the other --either orally or in writing-to cooperate (shirkah) in an affair. ${ }^{33}$ Then, the others accept the shirkah. Therefore, the agreement to only perform shirkah is still considered insufficient, including an agreement to provide capital for shirkah only is also still considered not enough, but must contain the meaning of cooperation (doing shirkah) in a business affair.

The initiators of Warung Sate Joenedin consisted of three initiators who cooperated by making the initial agreement related to determining the amount of initial capital, profit sharing, objectives to be attained, and the division of responsibilities and problem solving. Therefore, three initiators of Warung Sate Joenedin deposit their respective assets to be managed together by involving their abilities in running their businesses. The capital/ investment in the early establishment of the Warung Sate Joenedin was money and skills to process and cook the lamb. Warung Sate Joenedin was not opened from loans or debt. Although there was a loan offer from Bank to build the business, Jojo and his friends did not want to take it. It happens because, even though there was a little loan from the bank, it must have interest or usury. Since a business is not only seeking profit, but also the blessing in running a business that becomes the main point.

There is no requirement in a business stating that the total value of each wealth for a company should be the same. However, the wealth of each party is valued by the same standard. In this case, Warung Sate Joenedin admits the involvement in managing wealth, which is the same. The profit sharing is those who agreed that the profit is divided equally. Besides that, the loss burden from partners that must be borne in shirkah al-inan is only determined based on their wealth value. If the wealth of each party has the same value, the loss must be borne by each party equally.

\section{Profit and Loss Sharing}

The profit is based on mutual agreement, while a loss borne by each company (sharik) is based on the initial capital portion. For example, if each capital is 50 percent, each loss is borne in 50 percent. Abdur Razaq narrated that Ali ibn Abi Thalib, once says that loss is based on the amount of capital, whereas profit is based on their agreement (the party who does shirkah).

Due to the capital is divided equally at the beginning for the MSMEs of Warung Sate Joenedin, so profit and loss sharing is divided equally following its capital. It is as narrated by Abdur Razaq. In Warung Sate Joenedin, a profit sharing is carried out at the end of each month, while the loss still never exists. The profit sharing is divided into a company, namely, Jojo, Nedi, and Idin.

\footnotetext{
${ }^{33}$ Nur Syamsiyah, "Analisis Praktik Akad Syirkah".
} 


\section{The Advantages of Cooperation}

The establishment of cooperation that follows Islamic law, hence, here are the advantages of cooperation. ${ }^{34}$ First, the emergence of moral and material responsibility from each party. Implementing the cooperation contract makes the partner serious and responsible regarding the ownership feeling of Warung Sate Joenedin. Second, the appearance of a sense of serenity and satisfaction from each party due to the results obtained is following the efforts, which are eventually made partners satisfied. Third, avoiding disputes from each party. Fourth, avoidance of legal ownership of something. Fifth, the status of ownership of something (assets) becomes clear. Sixth, it should not be arbitrary in denying a cooperation agreement because it has regulated in Islamic law. Seventh, there is a strong bond in transacting or owning something. Eighth, with the contract, then, there is legal protection in the ownership of something.

\section{Obstacles}

Warung Sate Joenedin just opened. So far, there are no problems or obstacles during the implementation of this shirkah cooperation contract. The division of responsibilities is clear. In addition, the profit sharing agreement is obviously at the beginning of establishing Warung Sate Joenedin.

\section{Conclusion}

Based on the output in the research above, it can be concluded that, first, the cooperation formed in Warung Sate Joenedin business is a form of cooperation in the shirkah al-inān where shirkah al-inān is shirkah between two or more parties, each of which contributes work (charity) and capital. Both advantage and benefit obtained is a profit sharing that has been agreed by each party who carries out the contract. According to obstacles experienced, there were still no obstacles because the contracts agreed were based on the helping principles and minimizes disputes. Each party always held a meeting every month. The implementation of shirkah al-inan has a better implication for the growth of MSMEs and can be a solution for the surrounding community to create jobs so that it can improve the worker's income and reduce the unemployment rate, so the economic balance amid society makes the Indonesian economy stronger.

\section{References}

al-Nabhani, Taqiyuddin. Membangun Sistem Ekonomi Alternatif: Perspektif Islam, Trans. Moh. Maghfur Wachid. Surabaya: Risalah Gusti, 1996. . Sistem Ekonomi Islam. Bogor: Al Azhar Press, 2010.

al-Qardhawi, Yusuf. Norma dan Etika: Ekonomi Islam, Cet. 2. Jakarta: Gema Insani Press, 1997.

Aryansah, Januar Eko, and Dwi Mirani. "Strategi Bertahan Usaha Mikro Kecil dan Menengah Sektor Kuliner di Masa Pandemi Covid-19." Prosiding Applicable Innovation of Engineering and Science Research, Number 1 (2020).

\footnotetext{
34 Nurhadi, "Rahasia Hikmah di Balik Akad-Akad dalam Ekonomi Islam," Jurnal Ilmiah Ekonomi Islam, Volume 5, Number 1 (2019), 42-65.
} 
Chapra, M. Umar. Islam dan Tantangan Ekonomi: Islamisasi Ekonomi Kontemporer. Surabaya: Risalah Gusti, 1999.

Fadhilah, Nurul. "Strategi Manajemen Distribusi Islam dalam Mengatasi Krisis Ekonomi Akibat Pandemi Covid-19." Business Innovation and Entrepreneurship Journal, Volume 2, Number 4 (2020). . "Sumbangan Pemikiran dan Perspektif Akademisi." Politala Press, 2020.

Ghoni, M. Junaidi. Metodologi Penelitian Kualitatif. Jogjakarta: Ar-Ruzz Media, 2012.

Hamza, Lies Maria and Devi Agustien. "Pengaruh Perkembangan Usaha Mikro, Kecil, dan Menengah Terhadap Pendapatan Nasional Pada Sektor UMKM di Indonesia." Jurnal Ekonomi Pembangunan, Volume 8, Number 2 (2019).

Hardilawati, Wan laura. "Strategi Bertahan UMKM di Tengah Pandemi Covid-19." Jurnal Akuntansi dan Ekonomika, Volume 10, Number 1 (2020).

Haroen, Nasrun. Fiqh Muamalah. Jakarta: Gaya Media Pratama, 2000.

Juliana, J., et al. "Shirkah: Implementation of Fresh Water Fishing Fishery (KJA)." Tsarwatica (Islamic Economic, Accounting, and Management Journal), Volume 1, Number 2 (2020).

Mardani. Fiqh Ekonomi Syari'ah: Fiqh Muamalah. Jakarta: Persada Media Group, 2013.

Masadi, Ghufron. Fiqh Muamalah Kontekstual. Jakarta: PT. Raja Grafindo Persada, 2002.

Nurhadi. "Rahasia Hikmah di Balik Akad-Akad dalam Ekonomi Islam." Jurnal Ilmiah Ekonomi Islam, Volume 5, Number 1 (2019).

Ratnaningtyas, Endah Marendah. "Dampak dan Strategi UMKM (Usaha Mikro Kecil dan Menengah) Menghadapi The New Normal.” EBBANK, Volume 11, Number 1 (2020).

Sandy, Kunthi Fahmar. "Survei BI: 72,6 Persen UMKM Turun Omzet Akibat Pandemi Covid-19," 2020. Dalam https://www.inews.id/finance/makro/survei-bi-726-persenumkm-turun-omzet-akibat-pandemi-covid-19. Diakses pada 11 Desember 2020.

Sarfiah, Sudati Nur, et al. "UMKM Sebagai Pilar Membangun Ekonomi Bangsa.” Jurnal REP (Riset Ekonomi Pembangunan), Volume 4, Number 2 (2019).

Saripudin, Udin. “Aplikasi Akad Syirkah dalam Lembaga Keuangan Syariah.” Al Amwal (Hukum Ekonomi Syariah), Volume 1, Number 1 (2018).

Setiawan, Deny. “Kerja Sama (Syirkah) dalam Ekonomi Islam.” Jurnal Ekonomi, Volume 21, Number 3 (2013).

Sugiri, Dani. "Menyelamatkan Usaha Mikro, Kecil dan Menengah dari Dampak Pandemi Covid-19." Fokus Bisnis: Media Pengkajian Manajemen dan Akuntansi, Volume 19, Number 1 (2020).

Sugiyono. Metode Penelitian Bisnis Pendekatan Kuantitatif, Kualitatif, dan R\&D. Bandung: Alfabeta, 2017.

Suprihatin, Wiwik. "Analisis Perilaku Konsumen Wisatawan Era Pandemi Covid-19 (Studi Kasus Pariwisata di Nusa Tenggara Barat).” Bestari, Volume 1, Number 1 (2020).

Syafe'i, Rahmat. Fiqih Muamalah. Bandung: Pustaka Setia, 2000.

Syamsiyah, Nur. "Analisis Praktik Akad Syirkah Pada Usaha Mikro, Kecil, dan Menengah (UMKM) Batik Berdasarkan Perspektif Taqiyuddin al-Nabhani: Studi Kasus di UD. Rengganis Collection, Desa Selowogo, Kecamatan Bungatan, Kabupaten Situbondo, Jawa Timur.” Thesis_-UIN Maulana Malik Ibrahim, 2019. 